https://helda.helsinki.fi

\title{
Agonism, Democracy, and Law
}

\section{Minkkinen, Panu}

Oxford University Press

2020-04-02

Minkkinen, P 2020 , Agonism, Democracy, and Law . in S Stern , M Del Mar \& B Meyler (eds) , The Oxford Handbook of Law and the Humanities . , 23 , Oxford University Press , Oxford , pp. 427-442 . https://doi.org/10.1093/oxfordhb/9780190695620.013.15

http://hdl.handle.net/10138/314207

https://doi.org/10.1093/oxfordhb/9780190695620.013.15

acceptedVersion

Downloaded from Helda, University of Helsinki institutional repository.

This is an electronic reprint of the original article.

This reprint may differ from the original in pagination and typographic detail.

Please cite the original version. 


\section{Agonism, democracy, and law}

Panu Minkkinen

\section{Introduction}

Over the past few decades or so, various approaches to agonism have received much attention in political theory and neighbouring disciplines. Less so in legal studies even though agonism's central concern for democracy is central in law, as well. The scarcity of engagements in law is, perhaps, all the more surprising because Carl Schmitt, German jurist, constitutional theorist, and controversial critic of liberalism, is widely considered to be a forerunner, a 'proto-agonist', if you will, even if Schmitt's particular brand of 'antagonism' is different as this essay will also attempt to illustrate. In addition, the trial, or at least in its Anglo-American adversarial variety, could with good reason be regarded as a contemporary agonistic contest per excellence. ${ }^{1}$

Agonism can be defined as a theoretical position from which institutions, procedures, and principles reveal themselves through the political struggles and contestations that characterise them. So, for example, the distinguishing feature of law so understood would be the numerous interest conflicts that are managed and litigated by legal means rather than the mechanisms through which that management is executed. Moreover, and in political agonism in particular, the existence of these contestations is understood as a prerequisite of democracy. There can be no democracy without disagreement, this argument claims, and a society without disagreement is both impossible and undesirable. In this sense, agonism represents a challenge to the fundamental commitments of political liberalism, and in particular to the idea that the legitimacy of a political regime could somehow be inferred from a 'deliberative' consensus among rational actors.

Because democracy is the thematic filter through which agonism is viewed here, other aspects will necessarily be bracketed out. My aim is two-fold. After examining the philosophical origins of agonism, I will attempt to situate political agonism within the parameters of law and legal studies by drawing on insights from key theorists including Carl Schmitt, Chantal Mouffe, William E. Connolly, and Bonnie Honig. This perhaps conventional selection of key thinkers may imply a correspondingly conventional description of agonism itself. Indeed, the selection may serve those who are not familiar with the notion of agonism. But this is not my main aim. The specific interpretation that I am trying to defend here is embedded in the narrative undertow of the essay. Agonism in law, as it is understood in this essay, is an attempt to capture a critical post-Marxist and Nietzschean position, an attempt that should be seen against the dominant tradition of political liberalism in legal studies.

Martha Nussbaum, seemingly quite unaware of the antagonistic tone of her own intervention, has famously asserted that whatever contributions Friedrich Nietzsche may have made to moral psychology, he cannot be taken 'seriously' as a political thinker. ${ }^{2}$ Nussbaum's reservations are emblematic of how the liberal tradition sees Nietzsche and things Nietzschean, and how it positions itself in relation to agonism, as well. What should we, then, make of Nietzsche's influence on, say, Hannah Arendt? ${ }^{3}$ Or Max Weber? ${ }^{4}$ Are Arendt and Weber not 'serious' political thinkers? So in this

\footnotetext{
${ }^{1}$ See Rex Ferguson, 'Trials', in this volume.

${ }^{2}$ See Martha Nussbaum, "Is Nietzsche a Political Thinker?", International Journal of Philosophical Studies 5 (1997): $1-13$.

${ }^{3}$ See e.g. Margaret Canovan, Hannah Arendt. A Reinterpretation of Her Political Thought (Cambridge: Cambridge University Press, 1992).

${ }^{4}$ See e.g. Robert Eden, Political Leadership and Nihilism. A Study of Weber and Nietzsche (Tampa, FL: University
} 
essay I will also try to flesh out the Nietzschean undertow in agonism and to discuss its potential for developing a critical position that is decidedly post-Marxist. The advantages would seem to be obvious. By coupling democracy and interest conflicts to a theory of social and political struggles, agonism is a serious contender to liberal theories of law and politics because it provides a more fitting framework for understanding the democratic role of legal and political institutions in late modernity.

\section{The agon}

The term 'agonism' is derived from the Greek word áyóv (agōn). Liddell and Scott's standard lexicon defines the word as 'a gathering' or 'an assembly', especially in relation to games, and more generally as 'struggle' and 'contest'. 5 Indeed, the word was widely used for the games and contests, be they athletic or performative, that were organised in the various regions of ancient Greece and that eventually developed into the Panhellenic games at Olympia. ${ }^{6}$

In 1872, Friedrich Nietzsche wrote a short essay called 'Homer's Contest', 7 usually regarded as one of his 'early writings' before his unique brand of philosophy had developed into full maturity. It was published immediately after The Birth of Tragedy, ${ }^{8}$ his first major work, and seemingly intended as an introduction to a new book. In the essay, the young professor at Basel is still reading his Greek texts with at least traces of the pedantry of a classical philologist although recognisable themes and angles are already present. Many regard the text as both a tribute to and maybe even a challenge to his colleague and mentor at Basel, the Swiss historian Jacob Burckhardt, who had used the centrality of the agon in Greek life as a way of depicting one of the major historical phases in the development of Hellenic culture. ${ }^{9}$ And yet, at the same time, and clearly unlike his more reserved Swiss colleague, Nietzsche manages to extract from his sources an image of a dark preHomeric world the tensions of which are subsequently played out in the agonistic contest. Nietzsche warns us that, because of our modern sensibilities, we tend to be too captivated by the elegance of the regulated contest itself. This warning is most likely Nietzsche's stab at Burckhardt. And so he insists that if we wish to understand the Greeks properly, we need to refocus our attention on the dark forces that the contest is meant regulate:

Presses of Florida, 1983).

${ }^{5}$ Henry George Liddell and Robert Scott, A Greek-English Lexicon, 8th ed. (Oxford: Clarendon Press, 1901$), 18$.

${ }^{6}$ On the Greek agon, see e.g. Elton T. E. Barker, Entering the Agon. Dissent and Authority in Homer, Historiography and Tragedy (Oxford: Oxford University Press, 2009) and Thomas F. Scanlon, Eros and Greek Athletics (Oxford: Oxford University Press, 2002). For a modern literary interpretation, see Harold Bloom, Agon. Towards a Theory of Revisionism (New York: Oxford University Press, 1982).

${ }^{7}$ Friedrich Nietzsche, "Homer's Contest", 174-81 in Friedrich Nietzsche, On the Genealogy of Morality (Cambridge: Cambridge University Press, 2007). See also Ken Gemes and John Richardson (eds.), The Oxford Handbook of Nietzsche (Oxford: Oxford University Press, 2013). On Nietzsche as a political thinker, see e.g. David Owen, Maturity and Modernity. Nietzsche, Weber, Foucault and the Ambivalence of Reason (London: Routledge, 1994), Daniel W. Conway, Nietzsche and the Political (London: Routledge, 1997) and Keith Ansell-Pearson, ed., Nietzsche and Political Thought (London: Bloomsbury, 2013).

${ }^{8}$ In Friedrich Nietzsche, The Birth of Tragedy and Other Writings, trans. Ronald Speirs (Cambridge: Cambridge University Press, 1999).

9 Jacob Burckhardt, The Greeks and Greek Civilization, trans. Sheila Stern (New York: St Martin's Griffin, 1999), 160213. On Arendt and the agon, see Hannah Arendt, The Human Condition, 2nd ed. (Chicago: University of Chicago Press, 1998), 41, reference deleted, and Emilios Christodoulidis and Andrew Schaap, "Arendt's Constitutional Question," 101-16 in Marco Goldoni and Christopher McCorkindale, eds., Hannah Arendt and the Law (Oxford: Hart, 2012), 108-13. 
Hellenic popular teaching commands that every talent must develop through a struggle: whereas modern educators fear nothing more than the unleashing of so-called ambition. Here, selfishness is feared as 'evil as such' ... But for the ancients, the aim of agonistic education was the well-being of the whole, of state society. ${ }^{10}$

There are, perhaps, two points worth noting here. First, contrary to facile interpretations, Nietzsche is more interested in the regulated contest, that is, how a set of rules and practices manage to distinguish a victor, than in the brute force of an unregulated clash. The agon is, then, not an attempt to mask an unstructured confrontation. It is, rather, a way to channel the forces that are at play in the clash into a positive value. But second, and perhaps slightly contradicting the earlier point, he does ask an important question. If behaviour in the contest is regulated, then we need to ask why. What are the forces that animate a behaviour that seems to require regulation in the first place? This latter point is the 'dark' pre-Homeric Greece that sets Nietzsche's reading apart from the classical philology of his time.

Walter Kaufmann went on to explain the development of the agon as a thematic preoccupation for Nietzsche in the following way:

Nietzsche had previously considered the contest (agon) the most fruitful concept for any analysis of Greek culture. He had thought not only of the rivalry of the ancient dramatists who vied with each other for the highest prize, but also of the Olympic games and the Greek gymnasium; of Plato's effort to outdo the Sophists and the poets by composing more beautiful myths, speeches, and dialogues than they had ever conceived; and of the Socratic dialectic, which he understood as a spiritual contest. Now [in Daybreak from 1881] it occurred to him that the contest itself was a manifestation of the will to power. ${ }^{11}$

There is, then, clearly more at stake than just an isolated early text. The philosopher and Nietzsche scholar Christa Davis Acampora is one of the few who have dealt with Nietzsche's text as more than a mere curiosity or as just a way-station to Nietzsche's supposedly more mature philosophy. Unlike most readings, Acampora's elegant book Contesting Nietzsche ${ }^{12}$ focuses on Nietzsche's essay, not only as part of a larger unfinished early project, but also as evidence of the beginning of a recurring theme that Nietzsche returns to in different ways time and again. Through detailed closereadings, she illustrates how the agon informs the development of Nietzsche's philosophy from the alleged 'early writings' to the later concept of will to power. For Nietzsche, the essential aspect of the contest is not the annihilation of a contestant as a form of agency but, as Acampora argues, the production of social meaning and value in the form of a regulated struggle. And in so far as the regulated struggle can produce meaning, it becomes affirmable for human existence. Elsewhere Acampora explains:

The agon provided Nietzsche with a graphic image of how meaning could be publicly produced and reproduced. Agonistic contest, for Nietzsche, is a potentially productive force that regulates without subjugating the interests of individuals, coordinating them without reducing them to the interests of the community, and provides a radical openness for the circulation of power that avoids ossification into tyranny. ${ }^{13}$

\footnotetext{
${ }^{10}$ Nietzsche, "Homer's Contest," 178.

${ }^{11}$ Walter Kaufmann, Nietzsche. Philosopher, Psychologist, Antichrist (Princeton: Princeton University Press, 1974), 192, references deleted.

${ }^{12}$ Christa Davis Acampora, Contesting Nietzsche (Chicago: University of Chicago Press, 2013).

${ }^{13}$ Christa Davis Acampora, "Naturalism and Nietzsche's Moral Psychology," in Keith Ansell Pearson, ed., A
} 
Once again, two points may be worth keeping in mind. First, in Acampora's reading, the agon is not merely a forerunner to will to power or a precursor to Nietzsche's more mature philosophy as, for example, Kaufmann's interpretation suggests. As a theme, the agon extends from the early days of 'Homer's Contest' to the better-known latter books and texts and is interlinked with Nietzsche's other major themes in more intricate and complex ways. Second, and perhaps more importantly, Acampora does not regard the agon as merely a thematic focus in Nietzsche's philosophy. It is also the template for his own 'agonistic' engagement with the texts and characters that he chooses to take on.

Within the broader framework of political theory, agonism is, then, a particularly Nietzschean theme. It is both a thematic preoccupation with conflicting political interests and values, and a way of engaging with a dominant tradition. And it is this Nietzschean motif that this essay is trying to uncover.

\section{Antagonism, enemy, and existential threat}

How does an agonistic Nietzschean position translate into something related to legal studies? It is once again worth noting that although some engagements with Nietzsche do exist in legal studies, none of them deal with the theme of agonism. ${ }^{14}$ So the introduction of the agon would require a detour.

Carl Schmitt, German jurist, constitutional theorist, and unrelenting critic of liberalism, can be taken as our 'proto-agonist', as the starting point of what we could call an agonistic theory of law despite the fact that Schmitt's Nietzschean affiliations are far from clear. ${ }^{15}$ In addition, Schmitt will often be regarded as such a controversial figure that he is ill suited to provide any kind of critical framework for the analysis of modern democracy. ${ }^{16}$ Such views will be informed by Schmitt's harsh criticism of the Weimar Republic and its constitutional arrangements as well as his highly dubious political involvement in the Nazi regime that earned him the nickname 'Crown Jurist of the Third Reich. ${ }^{17}$ But at the other end of the political spectrum, there has also been a revived interest in Schmitt's work among left-leaning political theorists like Chantal Mouffe (who will be treated in more detail below), Wendy Brown, ${ }^{18}$ and Giorgio Agamben, ${ }^{19}$ sometimes through intermediate

Companion to Nietzsche (Oxford: Blackwell, 2006), 314-33, 328.

${ }^{14}$ E.g. Peter Goodrich and Mariana Valverde, eds., Nietzsche and Legal Theory. Half-Written Laws (Abingdon: Routledge, 2005), that does not even mention the word.

${ }^{15}$ See however John P. McCormick, Carl Schmitt's Critique of Liberalism. Against Politics as Technology (Cambridge: Cambridge University Press, 1997), 83-117 and Ciano Aydin, "The Struggle Between Ideals: Nietzsche, Schmitt, and Lefort on the Politics of the Future," in Herman W. Siemens and Vasti Roodt, eds., Nietzsche, Power and Politics. Rethinking Nietzsche's Legacy for Political Thought (Berlin: de Gruyter, 2008), 801-17.

${ }^{16}$ On Schmitt in general, see e.g. Reinhard Mehring, Carl Schmitt: A Biography, trans. Daniel Steuer (Cambridge: Polity, 2014), and Matilda Arvidsson, Leila Brännström, and Panu Minkkinen, eds., The Contemporary Relevance of Carl Schmitt. Law, Politics, Theology (Abingdon: Routledge, 2016).

${ }^{17}$ E.g. Peter Stirk, Carl Schmitt, Crown Jurist of the Third Reich. On Preemptive War, Military Occupation, and World Empire (Lewiston, NY: Edwin Mellen Press, 2005).

${ }^{18}$ E.g. Wendy Brown, Walled States, Waning Sovereignty (New York: Zone, 2010).

${ }^{19}$ Especially Giorgio Agamben, Homo sacer. Sovereign Power and Bare Life, trans. Daniel Heller-Roazen (Stanford: Stanford University Press, 1998) and Giorgio Agamben, State of Exception, trans. Kevin Attell (Chicago: University of Chicago Press, 2005). 
figures like Hannah Arendt and Max Weber. ${ }^{20}$ What, however, unites the different positions is that they are all engaged in a debate about the shortcomings of political liberalism. And it is in his critique of political liberalism where Schmitt develops what might be understood as a prototype of an agonistic theory of law.

The central argument that Schmitt puts forward in his famous 1932 pamphlet The Concept of the Political $^{21}$ is fairly well-trodden territory: in order for something to be truly political, it must include within itself a distinction between friend and enemy. For our purposes here, it will be useful to begin with the following often-quoted passage:

all political concepts, images, and terms have a polemical meaning. They are focused on a specific conflict and are bound to a concrete situation; the result (which manifests itself in war or revolution) is a friend-enemy grouping, and they turn into empty and ghostlike abstractions when this situation disappears. Words such as state, republic, society, class, as well as sovereignty, constitutional state, absolutism, dictatorship, economic planning, neutral or total state, and so on, are incomprehensible if one does not know exactly who is to be affected, combated, refuted, or negated by such a term. ${ }^{22}$

The friend-enemy distinction reveals itself, then, in the 'polemical' nature of all politics. ${ }^{23} \mathrm{~A}$ bit earlier in the text, Schmitt associates this polemical nature of politics with 'antagonism':

The political is the most intense and extreme antagonism, and every concrete antagonism becomes that much more political the closer it approaches the most extreme point, that of the friend-enemy grouping. In its entirety the state as an organized political entity decides for itself the friend-enemy distinction. ${ }^{24}$

In other words, the friend-enemy distinction that Schmitt sets out as a precondition of true politics is an antagonistic encounter. Moreover, Schmitt speaks of 'concepts, images, and terms.' So what Schmitt means by the political does not only concern concepts like 'democracy', 'constitution' and 'law' as theoretical categories. It also refers to imagery and less-than-conceptual expressions and notions. Think of, for example, the metaphorical power of the expression 'we, the people' in the Preamble of the US Constitution or, in its plural form, in the Preamble of the UN Charter ${ }^{25}$ In both cases, the expression identifies a 'people' (or a community of 'peoples') united by, perhaps, a common system of beliefs. The belief system is political in as much as the expression implies an 'other' that does not belong to the 'we' and that, by its mere existence, poses a threat to the unity and coherence of the 'we'. Hence antagonism and enmity, hence political.

Schmitt's understanding of the political is best exemplified through his main scholarly interest, namely constitutions. For Schmitt, a constitution is never merely a collection of conceptually

\footnotetext{
${ }^{20}$ E.g. Andreas Kalyvas, Democracy and the Politics of the Extraordinary. Max Weber, Carl Schmitt, and Hannah Arendt (Cambridge: Cambridge University Press, 2008).

${ }^{21}$ Carl Schmitt, The Concept of the Political, Trans. George Schwab, expanded ed. (Chicago: University of Chicago Press, 2007).

${ }^{22}$ Schmitt, The Concept of the Political, 30-31.

${ }^{23}$ See also Gregory Fried, Heidegger's Polemos. From Being to Politics (New Haven: Yale University Press, 2000).

${ }^{24}$ Schmitt, The Concept of the Political, 29-30.

${ }^{25}$ See Jacques Derrida, "Declarations of Independence," in Jacques Derrida, Negotiations. Interventions and Interviews, 1971-2001 (Stanford: Stanford University Press, 2002), 46-54.
} 
formalised laws that would define and delimit the competence of the state's political and legal institutions. This would be the standard claim of public law scholarship. A constitution will always include within itself an 'existential' dimension ${ }^{26}$ that Schmitt, in his monograph Constitutional Theory which is more or less contemporaneous with The Concept of the Political, elaborates with the help of the notion of an 'absolute concept of the constitution'. So what would an 'absolute concept' imply?

As a 'relative concept', the constitution would simply refer to the multitude of legal norms that have been legislated as constitutional norms. As such a multitude, these norms lack the 'unity' that is characteristic of the constitution as an absolute concept. ${ }^{27}$ The 'absolute concept' is, then, Schmitt's reference to the concrete way in which constitutional norms come together to form a unity. So Schmitt seems to suggest that unity as 'one' is specifically political by nature. Or, to be more exact, 'unity' is always a reference to the 'political unity of the people', ${ }^{28}$ the 'peculiar form of existence ... determined through the act of constitution making' ${ }^{29}$ Individualised existence as a unity is, in other words, political existence that can be achieved by embedding the institutions and practices that are necessary for said existence in a constitution. Here we are not far from the idea of a 'we, the people' that determines itself with the help of a set of constituted institutions and practices.

Nevertheless, at this point the more specific meaning of the word 'political' is still relatively formal. The only hint seems to be the unitary character of the whole: unity in relation to an 'enemy' is what makes existence political. Later in the book Schmitt further elaborates that this unity is closely related to what he calls the 'principle of identity', that is, the possibility of a people to recognise itself as a political unity in so far as 'by virtue of its own political consciousness and national will, it has the capacity to distinguish friend and enemy' ${ }^{30}$ So a people that has the will and the capacity to identify its enemy unifies itself according to the principle of identity and, consequently, exists in an antagonistic and political way.

Schmitt further distinguishes three dimensions in the absolute concept of the constitution. First, in its absolute sense, the constitution can be regarded as the concrete and collective precondition of the political unity and the social order of a given state. It is 'some principle of unity and order, some decision-making authority that is definitive in critical cases of conflicts of interest and power' ${ }^{31}$ This first dimension is, in other words, a reference to how sovereign power is organised and exercised within the state. Although Schmitt does not specifically mention 16th century French jurist and state theorist Jean Bodin here, the idea is very close to Bodin's notion of sovereignty as the absolute power that unifies the households of a realm into a single commonwealth. ${ }^{32}$ The constitution may also refer to a particular political or social order or, in other words, to a specific way of governing and subjection that is indistinguishable from the political existence of the state. In this second absolute meaning, the constitution will be identical with, for example, monarchy, oligarchy or democracy, or with the form of the state as the 'form of forms' ${ }^{33}$ In this case,

\footnotetext{
${ }^{26}$ See Michael Marder, Groundless Existence. The Political Ontology of Carl Schmitt (London: Continuum, 2010).

${ }^{27}$ Carl Schmitt, Constitutional Theory, trans. Jeffrey Seitzer (Durham: Duke University Press, 2008), 67-74.

${ }^{28}$ Ibid., 59.

${ }^{29}$ Ibid., 76.

${ }^{30}$ Ibid., 247.

${ }^{31}$ Ibid., 59.

${ }^{32}$ See Jean Bodin, On Sovereignty, trans. Julian H. Franklin (Cambridge: Cambridge University Press, 1992) and Schmitt, Constitutional Theory, 101.

${ }^{33}$ Schmitt, Constitutional Theory, 60.
} 
Schmitt's reference to the form of the state as forma formarum may well be of Thomistic origin, and especially an allusion to the famous claim made by the German Renaissance scholar Nicholas of Cusa (1401-1464) about God as the 'form of all forms', as 'forma omnium formarum' . ${ }^{34}$ This interpretation seems to be aligned well with Schmitt's own theological inspirations. Finally, the third dimension of the absolute concept of the constitution emphasises the principle of the dynamic development of all political unities and the force and energy that enables this. For Schmitt, no political unity can remain static as the false etymology of the words 'state' and 'constitution' as status seems to imply. Any political unity, once established, must regenerate itself continuously:

Political unity must form itself daily out of various opposing interests, opinions, and aspirations.... The constitution is the active principle of a dynamic process of effective energies, an element of the becoming ... ${ }^{35}$

So the etymology of 'constitution' refers to the more complex stasis as a dynamic between a seemingly settled unity and its continuous regeneration, rather than a static status. The agonistic forces that are at play in the stasis are evident. ${ }^{36 * * *}$

Schmitt does, however, concede that the absolute concept of the constitution could also refer to 'fundamental legal regulation' or, in other words, to the closed system of the hierarchically ultimate legal norms as a whole, to the constitution as the "norm of norms, ${ }^{37}$ or a "norma normans non normata'. This would be the position of standard constitutional theory. ${ }^{38} \mathrm{Schmitt}$, of course, rejects this kind of pure normativism because a constitution would consequently be regarded as valid merely because it has been correctly inferred from a formal competence. A constitution can, Schmitt insists, be valid only if, in addition to any formal criteria, it has been backed by a factual ability to constitute or, in other words, by a factual power or authority that makes the act of constituting possible to begin with. The constitution is created by the will of a 'constitution-giving power', and the word 'will' is, for its part, an indication of a factually existing power as the source of a command: 'The will is existentially present; its power or authority lies in its being' ${ }^{39}$

Understood politically, law is 'concrete will and command and an act of sovereignty' ${ }^{40}$ In order to remain internally coherent, standard constitutional theory must remain silent about this political will that can actualise a legal norm into a valid command:

The constitution in the positive sense originates from an act of the constitution-making power. The act of establishing a constitution as such involves not separate sets of norms. Instead, it

\footnotetext{
${ }^{34}$ Nicolai de Cusa, De docta ignorantia/Die belehrte Unwissenheit. Buch II. Lateinisch - Deutsch, trans. Hans G. Senger. Dritte Aufl. (Hamburg: Meiner, 2013), 20/21.

${ }^{35}$ Schmitt, Constitutional Theory, 61.

36 'Stasis means in the first place quiescence, tranquility, standpoint, status; its antonym is kinesis, movement. But stasis also means, in the second place, (political) unrest, movement, uproar and civil war.' Carl Schmitt, Political Theology II. The Myth of the Closure of Any Political Theology, trans. Michael Hoelzl and Graham Ward (Cambridge: Polity, 2008), 123.

${ }^{37}$ Schmitt, Constitutional Theory, 62.

38 "The constitution in the formal sense is a certain solemn document, a set of legal norms that may be changed only under the observation of special prescriptions, the purpose of which it is to render the change of these norms more difficult. The constitution in the material sense. consists of those rules which regulate the creation of the general legal norms, in particular the creation of statutes." Hans Kelsen, General Theory of Law and State, trans. Anders Wedberg (Cambridge, MA: Harvard University Press, 1949), 124.

${ }^{39}$ Schmitt, Constitutional Theory, 64.

${ }^{40}$ Ibid., 187.
} 
determines the entirety of the political unity in regard to its peculiar form of existence through a single instance of decision. This act constitutes the form and type of the political unity, the existence of which is presupposed. ${ }^{41}$

Already in these preliminaries that frame the further analyses in Constitutional Theory, one can rather easily detect Schmitt's own antagonistic confrontation with standard constitutional theory and the positivistic tradition of public law..$^{42}$ A constitution is, in other words, not simply the 'charter' of the liberal Rechtsstaat that limits its own powers through constitutional competences. It is the outcome of a constitution-giving power through which the constituent subject - in the case of democracy 'the people' - both establishes the institutions and practices that are essential for its political existence as a unified 'one' and secures them against potential threats by identifying an enemy. Constitutional institutions and practices are, then, 'constituted' for the very reason that political unity is potentially threatened by 'enemies', and it is the threat of such 'enemies' that also makes constitutions political in Schmitt's meaning of the word, and his more general notion of law antagonistic.

\section{From antagonistic enemy to agonistic adversary}

There are, then, two points that could cast doubt on Schmitt's membership in the agonistic family. First, and if we are to stick with the undertow of this essay, his Nietzschean affiliations are far from clear. The few scattered references are anecdotal, indirect, or even critical. But Schmitt's ideological links to the German 'radical conservative' movement would certainly suggest a kinship..$^{43}$ Second, Schmitt never discusses agonism or the agon as such. His vocabulary is more centred on 'antagonism' and 'polemics'. But Schmitt's contribution to agonism as its main legal representative is more apparent in the way in which his theory have been developed further by Belgian-born political theorist Chantal Mouffe who, without a doubt, would be regarded as one of the main representatives of contemporary agonistic theory.

Mouffe enters the agon from a perspective that is literally less 'antagonistic' than Schmitt's, but clearly in line with what we today understand by 'agonism'. We can trace her theoretical pedigree to the post-Marxist notion of radical democracy that she developed in the 1980s together with her co-author Ernesto Laclau. ${ }^{44}$ And from there on she has refined and expanded the theory into her own brand of 'agonistic pluralism' which draws heavily on Schmitt. ${ }^{45}$ But instead of dwelling on the usual platitudes about the political escapades of the 'Crown Jurist', Mouffe has transformed her Schmittian starting points into a leftist critique of neoliberalism in which the passion of and for politics is central: 'Democratic politics cannot be limited to establishing compromises among interests or values or to deliberation about the common good; it needs to have a real purchase on people's desires and fantasies. ${ }^{46}$

\footnotetext{
${ }^{41}$ Ibid., 75.

${ }^{42}$ With Hans Kelsen in particular. See Lars Vinx (ed), The Guardian of the Constitution. Hans Kelsen and Carl Schmitt on the Limits of Constitutional Law (Cambridge: Cambridge University Press, 2015).

${ }^{43}$ See Göran Dahl, Radical Conservatism and the Future of Politics (London: Sage, 1999).

${ }^{44}$ Ernesto Laclau and Chantal Mouffe, Hegemony and Socialist Strategy. Towards a Radical Democratic Politics, 2nd ed. (London: Verso, 2001).

${ }^{45}$ See especially Chantal Mouffe, The Democratic Paradox (London: Verso, 2000) and Chantal Mouffe, On the Political (Abingdon: Routledge, 2005).

${ }^{46}$ Mouffe, On the Political, 6.
} 
Mouffe's take on political liberalism can well be described as the 'market model' of democracy. It is premised on the incompatibility of a truly democratic rule 'by the people, for the people', and the demands of large industrialised societies. As the complexity of such societies increases, so, too, do the contradictory interests and values that are embedded in them. In order to manage these complex combinations of contradictory interests and values, representative democracy would seem to provide a solution. The function of the democratic subject is to simply accept or to reject propositions that are put to it by the various interest groups. The result is an instrumentally bent variant of social stability, but one without values:

Individuals are portrayed as rational beings, driven by the maximization of their own interests and as acting in the political world in a basically instrumental way. It is the idea of the market applied to the domain of politics which is apprehended with concepts borrowed from economics. ${ }^{47}$

Mouffe then goes on to identify a critical position in relation to this type of instrumental variant of liberalism, a critique that can be said to be internal to liberalism itself: the tradition of deliberative democracy.$^{48} \mathrm{~A}$ deliberative critique, with its emphasis on establishing consensual agreement about contradictory interests and values through deliberation, is mainly concerned with the ethical vacuum that follows as a consequence from the forced stability of an instrumental notion of liberalism. What is, then, deliberative democracy as Mouffe sees it?

In Mouffe's view, the aim of democratic deliberation is to arrive at a consensual outcome that is both rational to the extent that it secures individual rights, and democratic in that it allows for political self-determination. But the consensual outcome of the deliberation is never meant to question the foundations of liberal democracy itself. According to the rational consensus or the 'covenant' that has been reached through deliberation, authority and the use of power must be publicly justified. But more importantly, reason and rationality are not merely instrumental notions as in how to accumulate and distribute national wealth in the most efficient way. They are also normative.

Mouffe discusses in more detail especially two problems that are related to this notion of deliberative democracy. First, deliberative democracy seems to downplay the fact that the plurality of interests and values in democracy will inevitably lead to antagonistic clashes that cannot be resolved through deliberation. Not every socio-political disagreement is resolvable to the extent that the needs of all parties can be adequately satisfied. Second, in order to secure the consensual outcome of deliberation, power must be bracketed away from the equation because forced consensus is an oxymoron. Deliberative democracy is, then, a theory of democracy without power. And so, as a form of critique, deliberative democracy substitutes the economic instrumentalism of traditional liberalism with ethics, but at the expense of politics.

This is not enough for Mouffe. She calls for a theory of democracy that would recognise the specific nature of politics. Such a theory must acknowledge the part that power and antagonisms caused by conflicting interests and values play in society:

There are always other possibilities that have been repressed and that can be reactivated. The articulatory practices through which a certain order is established and the meaning of social

\footnotetext{
${ }^{47}$ Ibid., 12-13.

${ }^{48}$ See e.g. Amy Gutmann and Dennis F. Thompson, Why Deliberative Democracy? (Princeton: Princeton University Press, 2004).
} 
institutions is fixed are 'hegemonic practices'. Every hegemonic order is susceptible of being challenged by counter-hegemonic practices, i.e. practices which will attempt to disarticulate the existing order so as to install another form of hegemony. ${ }^{49}$

These ever-present counter-hegemonic practices represent Mouffe's debt to Nietzsche, as well:

some modes of life and some values are by definition incompatible with others and ... it is this very exclusion which constitutes them. We have to take Nietzsche's idea of the 'war of the gods' seriously and accept that, if there is no creation of an 'us' without delimiting a 'them', this relation may at any time become the site of an antagonism and the other may come to be perceived as an enemy..$^{50}$

So power is not something to be subtracted away from political life as 'unmanageable'. Quite the contrary, power and power relations constitute society. Deliberation seeks to minimise the effects of power from political life, but it is more important to seek out forms of power that are more in tune with democratic values. The ideal of democracy is not, Mouffe insists, a completely peaceful society.

Democratic politics, in Mouffe's terms, does not, then, aim at an impossible consensus but, rather, the ability to recognise an adversary while at the same time respecting her right to defend her own interests and values. This is where Mouffe departs from Schmitt. The term 'antagonism' depicts a battle between enemies, while 'agonism' is a conflict between adversaries. So for Mouffe, the objective of democracy is to transform social antagonism into political agonism, 'enemies' into 'adversaries'. The keys to such a political agonism are the pluralism of interests and values and passion as a driving force behind politics:

By the 'political', I refer to the dimension of antagonism that is inherent in human relations, antagonism that can take many forms and emerge in different types of social relations. 'Politics', on the other side, indicates the ensemble of practices, discourses and institutions which seek to establish a certain order and organize human coexistence in conditions that are always potentially conflictual because they are affected by the dimension of 'the political'. I consider that it is only when we acknowledge the dimension of 'the political' and understand that 'politics' consists in domesticating hostility and in trying to defuse the potential antagonism that exists in human relations, that we can pose what I take to be the central question for democratic politics..$^{51}$

Mouffe's 'agonistic adversary' resembles the way in which William E. Connolly describes 'agonistic respect' as a 'civic virtue that allows people to honor different final sources, to cultivate reciprocal respect across difference, and to negotiate larger assemblages to set general policies. ${ }^{52}$ Indeed, Connolly's book Identity Difference from 1991 can be regarded as one milestone in agonistic theory. Its affiliations with law are only indirect as it is more a theory about the politics of

\footnotetext{
${ }^{49}$ Mouffe, On the Political, 16.

${ }^{50}$ Chantal Mouffe, The Return of the Political (London: Verso, 1993), 127-28.

${ }^{51}$ Mouffe, The Democratic Paradox, 101. In her latest book, Mouffe discusses her theoretical differences with, e.g., Bonnie Honig, but she also puts her theory to work by examining specific topical issues such as globalization and Europe. Chantal Mouffe, Agonistics. Thinking the World Politically (London: Verso, 2013).

${ }^{52}$ William E. Connolly, Identity Difference. Democratic Negotiations of Political Paradox, expanded ed. (Minneapolis: University of Minnesota Press, 2002), xxvi.
} 
identity and difference, about the strained relationship between claims to some notion of the purity of a self-identity and the difference of an alter-identity called for by the very idea of democracy.

The democratic politics that might be able to address the strained relationship between self-identity and alter-identity Connolly calls agonistic democracy, that is, a 'practice that affirms the indispensability of identity to life, disturbs the dogmatization of identity, and folds care for the protean diversity of human life into the strife and interdependence of identityldifference. ${ }^{53}$ Unlike the idealism of communitarian variants of democracy, agonistic democracy does not equate human dignity with rational consensus. Instead, it opens political spaces for agonistic relations of adversarial respect without fully exhausting the social. And so it enables other modalities of attachment and detachment. One important way in which one can enhance human dignity is by cultivating Connolly's idea of 'agonistic respect'. The agonistic element of this reciprocal respect does, however, set it apart from conventional ideas of, say, deliberative democracy:

the democratic contestation of settled identities and conventions can help to call forth a more robust affirmation of interdependence and strife in the politics of identity. Agonistic democracy, where each of these terms provides a necessary qualification to the other, furnishes the best political medium through which to incorporate strife into interdependence and care into strife. This virtue provides a powerful argument on behalf of democracy. It also provides considerations pertinent to the shape the ideal of democracy assumes in the latemodern age. ${ }^{54}$

Bonnie Honig's Political Theory and the Displacement of Politics from 1993, another milestone in the agonistic literature, is for the most part an elaboration of what she calls virtù theories of politics, that is, theories that view politics as a 'disruptive practice that resists the consolidations and closures of administrative and juridical settlement for the sake of the perpetuity of political contest. ${ }^{95}$ Her main interlocutors in this discussion are Nietzsche and Hannah Arendt. In the introductory chapter of the book, Honig does, however, give an excellent illustration of what it would mean if law was understood through the agonistic scheme of virtù politics. At the time of writing the book, the US Supreme Court had just reaffirmed a woman's constitutional right to abort a pregnancy, originally recognised in Roe v. Wade in 1973. But the decision in Planned Parenthood of Southeastern Pennsylvania v. Casey from 1992 imposed significant new restrictions to this right. Honig notes the surprise with which those who had originally fought for the right now had to acknowledge that the issue was once again being contested. In the meanwhile, after Roe v. Wade, advocates of the pro-life position had managed to redefine abortion as 'killing' and the opposing pro-choice position itself as 'anti-family'. The lesson to be learnt from this was that the agon in which the right to abortion had first been contested and won could not be shut down and stabilised with law. Indeed, that is not what law can do. The belief that a contentious political issue such as the right to abortion could be settled by law without remainder had ceded the agon to the pro-life movement and shifted the debate accordingly. One can - and should - embed rights in law, Honig stresses, but at the same time, one must also acknowledge the perpetuity of the agonistic contest:

To affirm the perpetuity of contest is not to celebrate a world without points of stabilization; it

\footnotetext{
${ }^{53}$ Ibid., X.

${ }^{54}$ Ibid., 193. On Connolly's own Nietzschean positions, see many of the individual essays in William E. Connolly, William E. Connolly. Democracy, Pluralism and Political Theory. Eds. Samuel Allen Chambers and Terrell Carver (Abingdon: Routledge, 2008).

${ }^{55}$ Bonnie Honig, Political Theory and the Displacement of Politics (Ithaca: Cornell University Press, 1993$), 2$.
} 
is to affirm the reality of perpetual contest, even within an ordered setting, and to identify the affirmative dimensions of contestation. It is to see that the always imperfect closure of political space tends to engender remainders and that, if those remainders are not engaged, they may return to haunt and destabilize the very closures that deny their existence. It is to treat rights and law as a part of political contest rather than as the instruments of its closure. It is to see that attempts to shut down the agon perpetually fail, that the best (or worst) they do is to displace polities onto other sites and topics, where the struggle of identity and difference, resistance and closure, is then repeated. ${ }^{56}$

Honig has returned to issues related to law in a number of books where her agonistic template is, perhaps, detectable between the lines rather than at the surface level of the text. ${ }^{57}$ But in one of her more recent books, she takes on another relevant aspect to agonism. Antigone, Interrupted ${ }^{58}$ is a complex and multifaceted reading and interpretation of Sophocle's tragedy bringing it masterfully together with 'conspirators' such as Arendt, Jacques Derrida, and Judith Butler. The main theme of the book is the politics of lament and mourning, but in the context of this essay, its opening chapter is informative in that it explores and expands on familiar agonistic themes.

Honig demonstrates how the familiar figure of Antigone represents a contemporary variant of humanism that focuses on vulnerability and suffering as something that is common to human existence. This would be evident in, for example, the way in which Antigone is portrayed as the heroic victim of Creon's might. Honig criticises such a 'mortalist' notion of humanism because it is both disempowering and politically incapacitating. No stranger to Nietzsche, Honig proceeds to show how the tragedy can also be read in the light of a life-affirming and almost vitalistic agonism by refocusing the interpretation on, for example, Antigone's contempt for her sister Ismene's cowardice. For Honig, this is a 'different humanism - an agonistic humanism - that might better inspire progressive democratic imaginations than common receptions of this ancient heroine as mortal (death-identified) or maternal (and mournful). ${ }^{59}$

\section{Between actuality and potentiality}

There is no doubt that there is also a kinship between agonism and certain forms of contemporary leftist political theory, especially of the French kind. Jacques Rancière, to take one prominent example, clearly thinks within similar parameters of disagreement and 'dissensus':

disagreement is not only an object of my theorization. It is also its method. Addressing an author or a concept first means to me setting the stage for a disagreement, testing an operator of difference. This also means that my theoretical operations are always aimed at reframing the configuration of a problem. ${ }^{60}$

\footnotetext{
${ }^{56}$ Ibid., 15-16.

${ }^{57}$ E.g. Bonnie Honig, Democracy and the Foreigner (Princeton, NJ: Princeton University Press, 2001), Bonnie Honig, Emergency Politics. Paradox, Law, Democracy (Princeton, NJ: Princeton University Press, 2009), and Bonnie Honig, Public things. Democracy in Disrepair (New York, NY: Fordham University Press, 2017).

${ }^{58}$ Bonnie Honig, Antigone, Interrupted (Cambridge: Cambridge University Press, 2013).

${ }^{59}$ Ibid., 30.

${ }^{60}$ Jacques Rancière, "The Thinking of Dissensus: Politics and Aesthetics," in Paul Bowman and Richard Stamp, eds., Reading Rancière (London: Continuum, 2011), 1-17 , 2. See also Jacques Rancière, Disagreement. Politics and Philosophy, trans. Julie Rose (Minneapolis: University of Minnesota Press, 1999), xi-xii, and Jacques Rancière, ”A Few Remarks on the Method of Jacques Rancière," Parallax 15 (2009): 114-23. On Rancière and Schmitt, see Panu Minkkinen, "Rancière and Schmitt: Sons of Ares?" 129-49 in Mónica López Lerma and Julen Etxabe, eds., Rancière
} 
But even in the light of the radicalness of the theorists I have in mind, ${ }^{61}$ it would, I believe, be misleading to characterise agonistic accounts of politics and society as 'Marxist' despite the fact that they focus on the social and political struggles of capitalist societies. While the starting points of Anglo-American agonists like Connolly and Honig often involve 'existential' (read:

'Nietzschean') interpretations of Hannah Arendt's political philosophy, ${ }^{62}$ many of agonism's contemporary continental European advocates like Mouffe and Rancière have, despite their Marxist roots, developed their positions into something decidedly more 'post-Marxist' ${ }^{63}$

If one wanted to capture the two starting points in a single idiom, I would be tempted to say that they both originate from a European idea of what I might call 'radical liberalism', a Nietzschean position represented by, among others, the hugely influential but also neglected French sociologist and social theorist Raymond Aron. ${ }^{64}$ Not only is Aron himself a direct influence for many of these contemporary French agonists, but through his philosophical readings of classic social theory, ${ }^{65}$ his Nietzsche is filtered and refined through intermediate figures like Max Weber. As such, Aron participates in a lineage of radical liberalism that could well cover agonism's more Anglo-American tradition, as well.

Indeed, Aurelian Craiutu claims that although Aron's brand of liberalism is at heart a 'doctrine of political moderation', it also has a distinctively eclectic ring to it providing it with both richness and enduring relevance. The eclecticism is a result from Aron's attempts to combine two seemingly contradictory traditions that Craiutu calls the perfectionist and the agonistic strands of liberalism:

The perfectionist strand is demonstrated by [Aron's] belief that social and political institutions can and should create the conditions for the harmonious moral and intellectual development of individuals in accord with the progress of civilization. The agonistic strand stems from [his] belief that, since political institutions are the result of both historical contingency and conscious design, rights and liberties can never be fixed, being the outcome of political conflict and various political settlements. ${ }^{66}$

and Law (Abingdon: Routledge, 2017).

${ }^{61}$ In addition to Rancière, I would include at least Claude Lefort, Pierre Rosanvallon and Marcel Gauchet in this loose school of agonism mos gallicus. On the three mentioned, see e.g. Wim Weymans, "Freedom through Political Representation: Lefort, Gauchet and Rosanvallon on the Relationship between State and Society," European Journal of Political Theory 4 (2005): 263-82. See also Christopher Tomlins, "Materialism and Legal Historiography. From Bachelard to Benjamin," in this volume.

${ }^{62}$ As analyzed in e.g. Seyla Benhabib, The Reluctant Modernism of Hannah Arendt, new ed. (Oxford: Rowman \& Littlefield, 2003).

${ }^{63}$ See e.g. Warren Breckman, Adventures of the Symbolic. Post-Marxism and Radical Democracy (New York: Columbia University Press, 2013) and Martin Breaugh, Christopher Holman, at al., eds., Thinking Radical Democracy. The Return to Politics in Post-War France (Toronto: University of Toronto Press, 2015).

${ }^{64}$ See e.g. Daniel J. Mahoney, The Liberal Political Science of Raymond Aron. A Critical Introduction (Lanham, MD: Rowman \& Littlefield, 1992) and José Colen and Elisabeth Dutartre-Michaut, eds., The Companion to Raymond Aron (New York: Palgrave Macmillan, 2015).

${ }^{65}$ Raymond Aron, Main Currents in Sociological Thought, vols $1 \& 2$, trans. Daniel J. Mahoney et al. (Abingdon: Routledge, 2017).

${ }^{66}$ Aurelian Craiutu, "Raymond Aron and the Tradition of Political Moderation in France," in Raf Geenens and Helena Rosenblatt, eds., French Liberalism from Montesquieu to the Present Day (Cambridge: Cambridge University Press, 2012), 271-90, 276-77. 
This 'eclectic combination' of 'perfectionist' progress and 'agonistic' contingency illustrates well the reasons why Nietzsche's contest is always able to produce positive values. Social and political values, be they institutionally embedded in constitutions, laws, or otherwise, are never in a freefalling flux even if this may seem to be the case if viewed from a particular moment in history. There are also moments when they enjoy relative success. Honig's example of Roe v. Wade is instructive. But a value that is currently actualised as a right does not guarantee that it will never be challenged, as the US Senate Judiciary Committee hearings taking place at the time of writing this essay bear witness. Conversely, a political defeat like an unfortunate judicial appointment is always a setback, and as such, it also marks the potential reinstatement of the value that was lost. In the agonistic contest, these values can only reach a strained existence between actuality and potentiality. 


\section{Further reading}

Finlayson, Alan, ed. Democracy and Pluralism. The Political Thought of William E. Connolly. Abingdon: Routledge, 2010.

Martin, James, ed. Chantal Mouffe. Hegemony, Radical Democracy, and the Political. Abingdon: Routledge, 2013.

Meierhenrich, Jens, and Oliver Simons, eds. The Oxford Handbook of Carl Schmitt. New York, NY: Oxford University Press, 2016.

Sawyer, Stephen W., and Iain Stewart, eds. In Search of the Liberal Moment. Democracy, AntiTotalitarianism, and Intellectual Politics in France since 1950. Basingstoke: Palgrave Macmillan, 2016.

Schaap, Andrew, ed. Law and Agonistic Politics. Aldershot: Ashgate, 2009.

Siemens, Herman W., and Vasti Roodt, eds. Nietzsche, Power and Politics. Rethinking Nietzsche's Legacy for Political Thought. Berlin: de Gruyter, 2008.

Wenman, Mark. Agonistic Democracy. Constituent Power in the Era of Globalisation. Cambridge: Cambridge University Press, 2013. 